\title{
African Anti-Colonialism and the Ultramarinos of the Casa dos Estudantes do Império
}

\author{
ALEXANDRA REZA \\ University of Oxford
}

\begin{abstract}
In this article, I examine the "space between" occupied by students at the Casa dos Estudantes do Império, a crucial nexus for independence campaigns in Lusophone Africa. Drawing on readings of the Casa's journal, Mensagem, I argue that the students saw political affiliation as a constant movement between formulations of "home" and "the world." I situate this dilaectical approach in the context of Portuguese fascism, paying particular attention to the political poetry published in Mensagem, and analyzing the ways in which members of the Casa imagined their relationship to other African anti-colonial movements.
\end{abstract}

Keywords: Mensagem; Liberation; Amílcar Cabral; Frantz Fanon; Poetry

On 26 March 1959, the Francophone psychiatrist and anti-colonial theorist Frantz Fanon addressed an audience at the Second Congress of Black Artists and Writers in Rome. "National claims, it is said here and there," he said, "are a phase which mankind has passed ... [and] the backward nationalists should therefore correct their errors. We think, on the contrary, that the error, heavy with consequence, would be to want to skip the national stage." Rather than narrowing the scope of politics, he suggested, "national construction will necessarily be accompanied by the discovery and encouragement of universalizing values ... it is in the heart of national consciousness that international consciousness arises and vitalizes itself" (96-97).

Fanon's words bring forward a number of themes that bear upon this article, which draws on archival research in journals published in Europe by African 
anti-colonialists between the 1940s and the mid 1960s. Fanon's speech is particularly notable for its expansions and contractions of political affiliation. He talks seriously about national consciousness and vigorously about African political unity in the face of colonialism; but he also talks about achieving a "new humanity ... a new humanism." Fanon was speaking on the eve of what would be, for much of the Anglophone and Francophone sub-Saharan continent, the annus mirabilis of African independence: in 1960, British Somalia, Cameroon, Central African Republic, Chad, Dahomey (later Benin), Democratic Republic of Congo (and the breakaway State of Katanga), Gabon, Italian Somaliland, Ivory Coast, Mali, Mauritania, Niger, Nigeria, Republic of Congo, Senegal, Togo, and Upper Volta (later Burkina Faso) all followed Guinea and Ghana in attaining national independence.

For Portugal's African colonies, the story was slower to unfold. They did not gain independence until around fifteen years after most British and French colonies in Africa: for Guinea-Bissau in 1973, and for Mozambique and Angola in 1975. It was in this context that, in January 1966 at the first Tricontinental Conference of the Peoples of Asia, Africa, and Latin America in Havana, the Bissauan leader Amílcar Cabral proffered a similarly oscillating conception of political community. For Cabral, the central task at hand involved forging "um Homem novo, plenamente consciente dos seus direitos e deveres nacionais, continentais e internacionais" (Unidade e Luta 199).

Cabral's and Fanon's words register both nationalist and cosmopolitan commitments. This lack of contradiction between nationalism and cosmopolitanism was typical of many African anti-colonialists, whose discourses and practices inscribed commitments and spatial imaginaries that critiqued and surpassed the nation-state even as they fought for national independence. For them, there was no stark choice to be made between their nation-to-be and humanity: the choice was strategic and temporally contingent rather than mutually exclusive. They saw nationalism as both necessary and insufficient to the greater goal of a wider freedom.

Existing scholarship tends to dance around this ambivalence, searching for the right formulation to describe the kinds of affiliative commitments entailed by this and other forms of Third-World anti-colonialism. Cemil Aydin considers the coexistence of nationalism with pan-nationalisms a "puzzle" (627). Vijay Prashad describes an "internationalist nationalism" (12). Glick Schiller suggests 
that pan-Africanisms ultimately serve to represent "subaltern and everyday forms of cosmopolitanism" (419). Rahul Rao talks about a productive "space between cosmopolitanism and nationalism" (8).

In this article, I examine what Rao's "space between" meant to students at the Casa dos Estudantes do Império in Lisbon, a center founded in 1944 by the Portuguese government with the intention of preparing overseas students for future imperial duties. The Casa became a crucial nexus for later independence campaigns in Lusophone Africa. There key figures from Mozambique, Angola, and Guinea-Bissau met, thrust together not only by their shared interest in decolonization but also by the particularly uncompromising response of the fascist Estado Novo regime to the anti-colonialism growing throughout European empires in the 1950s. A remarkable number of Lusophone African liberation fighters and early post-independence presidents were students there, including Cabral, Mário Pinto de Andrade (founder and first president of the MPLA), Eduardo Mondlane (the founding president of Frelimo), and Agostinho Neto (Angola's first President). ${ }^{1}$

Drawing on readings of Mensagem, the journal published by the students at the Casa between 1948 and 1964, I outline the conception of an ultramarino movement these students developed, arguing that these ultramarinos espoused an idea of political affiliation that was constantly moving between "us" and "them": between, in Rabindranath Tagore's formulation, "home" and "the world." In Mensagem, divisions between us and them are temporary, and never absolute. At the Casa, "we" was a community that had to be built, but whose boundaries were always receding from view in the face of humanity as a whole. Any strategic decision to prioritize some form of "us" is accompanied by a sense of opening out into a larger group. This back-and-forth, I suggest, provides a way of reading not only the relationship between Lusophone and Francophone

\footnotetext{
${ }^{1}$ Others included Fernando França Van Dúnem (former prime minister of Angola and first vice-president of the African Union's Pan-African parliament); Joaquim Chissano (second president of Mozambique); Manuel Pinto da Costa (first president of Sao Tomé e Príncipe); Mário Machungo (former prime minister of Mozambique); Miguel Trovoada (former prime minister and president of São Tomé e Príncipe); Pascoal Mocumbi (former prime minister of Mozambique); and Pedro Pires (former prime minister and then president of Cabo Verde). For more on the formation of political elites in Lusophone Africa, see Mateus.
} 
African anti-colonial groups, but also a way of thinking about the transnational solidarities of post-World War II anti-colonialism more generally. I will proceed in three parts. First, I discuss the development of Mensagem's dialectical approach in the context of Portuguese fascism. I then argue that this back-andforth movement between $u s$ and them - particular and general-is also palpable in Mensagem's political poetry. Finally, I examine how some of the Casa's members imagined their relationship to other African anti-colonial movements.

As Pires Laranjeira makes clear in his accounts of the Casa's history, Salazar's Estado Novo regime subjected editors and writers at Mensagem to stringent censorship. A letter from Sarmento Rodrigues (then Ministro do Ultramar) to Salazar in 1952 describes the government's increasing concern regarding how the center's putative function - to socialize students into imperial functionaries-was being subverted. Indeed, between 1952 and 1958, the introduction of government administrative oversight eventually caused Mensagem to cease to be published altogether. In 1965, the Estado Novo closed the Casa completely, after its politics had sharpened and armed conflict had broken out in Angola in 1961 and Mozambique in 1964 (Laranjeira, xviii-xix). The context of aggressive government censorship presents methodological challenges in terms of studying the Casa's history and publications; however, it is also in the context of political isolation and repression in Portugal that the Casa assumed its importance. As António Faria has argued: “A Casa dos Estudantes do Império foi um lugar de convivência, a unidade de uma diversidade de valores originais, onde se afirmaram e desenvolveram diferenças culturais dentro de uma perspectiva e possibilidades comuns.... [C]onsolidou laços indestrutíveis fundados em ideias de liberdade, de tolerância e de fraternidade" (21). In the end, the students who met and worked there resisted not only colonialism at home, but also widespread immiseration and tyranny on European soil.

\section{The ultramarinos}

Where the word "international" became common in English only in the early nineteenth century, the ultramar, the Portuguese noun for "the place over-thesea," which came to describe Portugal's empire, predates it by six hundred years (Machado 2270). It is a word that has long enjoyed a special imaginative freight in a country that even today remembers, in an often anesthetized version, its 
lengthy seafaring history (Power 133). The ultramar was an important concept for the students who came to the Casa from different countries. They called themselves ultramarinos, reclaiming the word as a term of self-identification.

Mensagem repeatedly characterizes its central project as one focused on building an ultramarino movement. We are, a 1958 article declared, "um grupo de rapazes de diversas províncias ultramarinas, desejosos de trabalharem em comum para constituírem presença e forca das terras de África e do Oriente na capital do Império" (Gomes 6). Building such a movement involved fostering "entre nós uma maior coesão e entendimento" and fighting "pelos nossos interesses" ("Editorial" (1959) 4). In this endeavor, the tension between singularity and diversity is central. It is only by "organizando-se numa unidade" suggests a 1960 editorial, that they can "enfrentar melhor os problemas comuns do estudante ultramarino, qualquer que fosse a sua raça o origem" (Monteiro 4).

The construction of the ultramarino movement was ongoing: a motivating ideal more than an achieved reality. To be an ultramarino was to embody a kind of "eterno tornar-se," which aspired to a "síntese suprema" of communality and particularity ("Editorial" (1959) 4). This tension between sameness and difference is what distinguished the Casa and Mensagem for their members. As they put it, the goal of Mensagem was to bring together "nos seus temas as essências das diferentes províncias ultramarinas ... será um instrumento de concatenação das diferentes expressões de cultura no sentido duma visão mais ampla e aberta das realidades ultramarinas" ("Editorial” (1963) 3-4).

If a particular kind of ultramarino unity was important for the students at the Casa, the Estado Novo was focused on a different kind of unity agenda. In particular, the aspiration for (and assertion of) a single, indivisible empire underpinned Salazar's regime. As Fernando Rosas reminds us, Portuguese colonialism has a past that began long before the Estado Novo government in the twentieth century; however, the Estado Novo changed the empire in important ways, both in terms of ideological paradigms and in terms of colonial policy (13). Even before he was installed as prime minister, Salazar had prepared the Ato Colonial, promulgated on 8 July 1930. This was a piece of legislation that changed the designation of the imperial territories from "províncias ultramarinas" to "colónias" for the first time. The legislation centralized economic, fiscal, and legislative power in Lisbon, and emphasized the unity of the metrópole with the empire's "partes componentes" while curtailing the 
financial and fiscal autonomy of the latter (Decreto n.18:570, Article 5). In reality, the Portuguese occupation of the main colonies was always limited, but the determination to consolidate Lisbon's power over its empire and never to relinquish its imperial project became a central tenet of Salazarist fascism and of its conception of Portuguese national identity. A self-justifying logic underpinned the Estado Novo's policies, which presented the empire as fundamental to Portugal's independence as a nation, and the regime as the only type of government that could keep hold of the colonies. In this way, the Estado Novo used the empire to cast itself as indispensable to the future of Portuguese independence (Rosas 14).

This emphasis on the unity of the empire shaped the structure of the organization in which the ultramarinos found themselves. Before the creation of the Casa in 1943, there existed separate, "national" Casas dos Estudantes: one for Angolan students, one for Mozambicans, one for Cabo Verdeans, one for Indians, and finally one for students from Macau. In the summer of 1944, the then minister for the colonies, Francisco Vieira Machado, oversaw the unification of these centers into one singular Casa. At stake from the regime's point of view, Rosas writes, was the need to "consagrar ... a unidade do império (não deveria haver casas separadas se o império era um só)" (15).

In 1951, as imperial projects were called into question around the world, the Ato Colonial was revoked, and the expression colónias was replaced again by províncias ultramarinas. The Ministério das Colónias became the Ministério do Ultramar. This rebranding, which might have seemed like a softening of the regime's position, was in reality accompanied by an even more trenchant defense of the imperial project. It was at this point that the Salazarist slogan, "Portugal uno e indivisível, do Minho a Timor," which gained currency in the 1960s, began to circulate (Sousa and Martins, 93). The Salazarist vision, Rosas argues, was of "um império inalienável, indiscutível, permanente que corresponde à própria essência da nação e portanto não se discute. É consagrada constitucionalmente a sua existência, é indivisível, não é negociável, é perene e permanente.... O império é essência da nação" (13).

The Casa's project of building an ultramarino movement was evidently a subversion of Salazar's conception of the word. The emphasis on unity without difference-the Estado Novo's vision - is useful in elucidating why unity with difference-Mensagem's vision-acquired such valency. Perhaps the most 
comprehensive elaboration of what it meant to develop an idea of ultramarino identity comes in one of the final essays Mensagem published, "Pelo que Lutamos," in which Alberto Rui Pereira, the vice-president of the Casa, articulates what he called the "rara visão ultramarina" (6). The Casa, he wrote, is a microcosm of the ultramarino world, and in this sense a place where people can be "universal" (6). Pereira's universal dimension seems to be referring to the way he sees the Casa as a place that brought together different people under a common project without imagining difference as something to be overcome. It is this integrative culture that, "como acção consciente e actividade crítica no seio duma realidade, como visão do mundo a da vida, "condiciona a liberdade, a toleráncia e a fraternidade"" (6). Pereira insists on one of Mensagem's signature themes, namely, that there is something valuable in the very coexistence of difference: "procuramos enriquecer-nos através do contacto permanente com actividades multilaterais e de interesse frontalmente cultural-duma cultura de pólo ultramarino, pronta a lapidar-nos funcionalmente para uma vida de mais saber, de mais humanismo e fraternidade" (43).

This nexus of cultural and geographical difference was both politically radicalizing and theoretically productive for students at the Casa. As Fernando Ganhão, a Mozambican student at the Casa writes, "Foi ... no confronto com as várias personalidades das colónias portuguesas de então que o sentido político despertou para mim" (151). For Manuel dos Santos Lima, an Angolan, it was the way in which the experience of the Casa allowed students from different colonies to generalize their situation that was powerful. He writes: "num certo momento bem preciso, permitiu troca de ideias; permitiu aos colonizados de todas as colónias portuguesas terem um ponto de encontro e sobretudo de consciencialização, de saberem que estavam todos irmanados por um problema comum que era uma luta de libertação" (153).

In February 1957, the Casa, which had previously organized itself in sections that grouped students together by colony, dissolved its sections, which were considered by the regime as centers of nationalisms (Castelo 25). By 1960, advisors to the Estado Novo had become increasingly concerned that overseas students "sejam rodeados dos cuidados materiais e espirituais necessárias à sua real integração no espírito de unidade nacional" (Castelo 27). The sense that the Casa's "tendências segregativas" were obstructing this project of dissolving difference into the absolute assimilation that might facilitate the empire's 
survival ultimately informed the regime's decision to shut it down (Castelo 27).

\section{Political poetry}

The Salazarist vision of an undifferentiated unity belied a highly stratified and racist conception of who should benefit from the empire. This is one reason that the poetry Mensagem published became so important. It brought into view the experiences of suffering and oppression that made anti-colonialism an aspiration. At its most basic level, the imaginative writing that the students of the Casa read and wrote summoned up other worlds of experience away from metropolitan Lisbon life. "Mudança," for example, a poem published in 1963 in Portuguese Creole by the Cabo Verdean poet Ovídio Martins, talks of the "luta de tude dia" on the land, the pain of "suor e trabói" that benefits someone else. "Riqueza de terra ê pa quem?" the poetic voice demands (45). This focus on the details of suffering recurs. "Se me quiseres conhecer," the Mozambican poet Noémia de Sousa begins her 1962 poem, "estuda com bom ver ... órbitas vazias no desespero de possuir a vida," and "[o meu] corpo tatuado de feridas visíveis e invisíveis / pelos chicotes da escravatura" (47).

Indeed, the publication of lyric poetry-which, often written in the first person, tends formally to emphasize the importance of personal experience and feeling - is another way in which Mensagem undertakes the work of connecting (and problematizing) the relationship between the general and the particular. In the context of the ultramarino movement, the poetry of personal experience became political because it refers to experiences that its readers share, and against which they organize.

The close link between politics and poetry became more acute in the last and final phase of the Casa's existence, exemplified by an essay published in 1963 by the São Tomensean poet Francisco José Tenreiro. "Não é por mera coincidência que os poetas povoam ao lado dos políticos, por essa Europa fora, as prisões," Tenreiro wrote. "Porque o poeta é um político? ... a Poesia é, por si só, a própria essência da humanidade" (6). We might be somewhat skeptical about these rather grand claims for the role of poetry as a privileged platform for expressions of "humanity." We might even consider them rather self-serving on the part of the poets that advocated this view. Yet African culture and writing had been systematically belittled and silenced in Europe for centuries, an attitude 
that had gone hand in hand with brutalizing and racist colonial policies. The reassertion of previously absent African subjectivity in Portugal at a moment when other European empires had already begun to crumble was inherently a politically charged and radical act: "Estamos perante," the then-director of the Casa Fernando Murão wrote in 1960, "o diálogo Europa-África”(9).

Indeed, many of the poems in Mensagem engage explicitly with the theme of presence. This is expressed, for example, in the Angolan poet Alda Lara's 1962 poem "Presença." The poem is an apostrophic address to "Mãe-Africa" and revolves around a dense assertion of subjectivity from a disembodied poetic voice speaking in the first person: "E apesar de todo / Ainda sou a mesma! / ... eternal" (10-11). Other poems are more explicitly political in theme, such as the Mozambican poet José Craveirinha's "Poema do Futuro Cidadão." In another text, "Sonho," Craveirinha talks of building a house of his own, an analogy for a new world, and a dreamed-of Africa:

Vou construir uma casa

Sem ódio...

Uma casa minha

Construída sem o sabor acra da pólvora nos lâbios gretados

Não é uma casa mas o mundo realizado...

será o homem que partiu sem um adeus no cais

e regressa na manhã dos gritos das crianças

a cantar áfricas

sonhadas ao longo da minha rua (25)

Beyond the formal work of generalizing particular experience that these poems undertake, there are moments of thematic concern with the relationship between "me" and "you"; "us" and "them"; "home" and the "world." Cabral's 1949 "Poema," for example, centers on the image of a cry of resistance traveling around the world. It is both a personal and universal phenomenon, a moment that is somehow able to vivify and also gather together humankind as a whole:

Meu grito de revolta ecoou pelos vales mais longínquos da Terra,

Atravessou os mares e os oceanos,

Transpôs os Himalaias de todo o Mundo, 
Não respeitou fronteiras,

E fez vibrar meu peito...

Meu grito de revolta fez vibrar os peitos de todos os Homens,

Confraternizou todos os Homens.... (16)

Read alongside each other, these poems suggest that these writers were deeply aware of and concerned by the structural and political constraints that inhibited their lives and the lives of their communities. At Mensagem, there was a strong sense that such poetic endeavors served and followed the ultramarinos' politics, which were global in scope. "As nossas tentativas poéticas," wrote Neto in 1960, follow a "visão panorâmica dum movimento mundial" (51). The poetry was also, however, a response to the assimilationist policies of the Salazar regime, poems that assert the specificity of ultramarino experience in the face of pressure to efface such assertions of difference in the name of an indivisible Portuguese empire.

\section{From the ultramarinos to the wider African liberation struggle}

Both in its poetry and in its conception of an ultramarino movement, we can see in the Casa a constant dialectic between particular and general. The Casa's attitude to the wider liberation struggle, including wider pan-African movements, was characterized by a similarly ambivalent sense that they were neither straightforwardly part of the same struggle, but also that they were part of something shared. Their attitude to other movements, especially Anglophone and Francophone movements, was always bifurcated between a sense that they were united under the auspices of anti-colonialism and by a strong assertion of the particularity of their own movement.

This is clear in the relationship between the Casa and Présence Africaine, the influential Francophone journal established in Paris in 1948 under the editorship of a Senegalese intellectual, Alioune Diop. In some ways, the two institutions shared a common frame of reference. Several writers at the Casa produced material for Présence Africaine and attended Diop's Black Artists and Writers Congresses in Paris in 1956 and Rome in 1959. In particular, Andrade, who was closely involved in Présence Africaine during his years in Paris, and Manuel dos Santos Lima both regarded the 1956 conference as a high point and 
politicizing moment in the Lusophone movement. The conference, at least for Lima, marked "uma etapa extremamente importante na minha vida intelectual na medida de que, pela primeira vez, estou em contacto com uma 'intelligentsia' negro-americana que reflete as minhas preocupações, não só dum ponto de visto espiritual, mas igualmente dum ponto de vista social e político. A festa da Negritude, que foi [o] encontro, foi também uma festa anticolonial.... Foram uns dias felicíssimos" (153).

The conference followed the publication of an article for a special edition of Présence Africaine in 1953 titled "Les étudiants noirs parlent" (Black students speak). Given the already repressive situation in Portugal (Mensagem was no longer being published at this time), the article was anonymous, but its authors included Francisco-José Tenreiro, Cabral, Neto, Andrade and the poet Alda do Espírito Santo. It moves between a sense of African and universal identity. "Tous les hommes réellement progressistes” 'All true progressives,' they wrote:

vivent aujourd'hui l'heure de la rencontre universelle. Aussi les étudiants africains cherchent à rattraper le temps perdu, dans la construction d'autres mondes et essentiellement, ils aspirant à être les porte-paroles de la libération de toutes les chaînes que entravent la marche du progrès ... en servant ainsi l'humanité. (229-36)

[live today at a time of universal confluence. African students also seek to make up for lost time in the construction of other worlds. Essentially, they aspire to serve humanity as the spokespersons for liberation from all the chains that obstruct the march of progress.]

This oscillation and juxtaposition of humanity and nationalism recurs. Even at its most radical and politicized in the early sixties, Mensagem still talks not only about the African struggle but also about what it sees as the expansive and noble objective of achieving "a comunhão universal das culturas" ("Editorial" (1963) 4). In this vision, the African struggle is united in a revolutionary goal that will change both their own situation and that of humanity as a whole.

More generally, Mensagem and Présence Africaine shared a sense of the close interrelation of culture and politics at that historical moment. "Dans un tel univers," Diop asked in his opening speech at the Paris conference, "comment 
concevoir que la culture et la politique appartiennent à deux mondes radicalement distincts?" 'In a world such as this ... how could we possibly conceive of culture and politics as belonging to two radically different worlds?' (11-13). Diop's comrades in Lisbon agreed with this rhetorical question, particularly as so many of the writers among them had been imprisoned by the PIDE, the security arm of Salazar's regime. In introducing their section within the anthology of black poetry published in Présence Africaine in 1966, the anonymous contributors from the Casa reiterated Tenreiro's analysis from 1963: "Cultura e política não andaram nunca dissociadas no contexto colonial. Só assim se explica que a maior parte dos poetas que figuram neste breve recolha - se encontrem à hora atual nas prisões portuguesas, em Lisboa ou em África, ou no exílio no estrangeiro" (434).

In the face of such a repressive regime, however, the Lusophone movement was more constrained in its view of what reading and writing could change, and it was emphatic that literary interventions were not the whole of political combat. Cabral's much-quoted phrase from the Havana Tricontinental Conference of the same year is fairly representative: "não é gritando nem atirando palavras feias faladas ou escritas contra o imperialismo, que vamos conseguir liquidá-lo" (201). Indeed, in this 1966 article, the Lusophone poets are concerned to emphasize their differences from Présence Africaine in terms of the importance Lusophone anti-colonial movements accorded to material questions, and in terms of their relationships to "ordinary" Africans. They present the Lusophone struggles as more engaged with the African people at the grassroots, in contrast to a Francophone cultural movement that, they implied, remained mainly concerned with questions of interest only to the intellectual élite. By contrast, they argued, the Lusophone movement sought to establish meaningful new social frameworks in the world (Breve nota explicativa 434). By then, the international situation had also changed radically, to the extent that in many senses the two groups were facing different realities. By this stage, while French colonies had realized independence, the Lusophone struggle had taken a strong turn towards direct action, as armed struggle had begun in Angola and Mozambique. The Casa and Mensagem had closed down. More than ever before, the challenges for the ultramarinos had decisively moved off the page and onto the ground.

The ultramarinos did not, however, set aside their literary work. Those involved with Mensagem clearly regarded poetry, and imaginative literature more broadly, as extremely valuable. For the poets at the Casa, imaginative work 
was only really political when it accompanied a more concrete conception of political activism. A strong sense of obligation to the world beyond culture is palpable throughout Mensagem. There is a strongly normative dimension to the role of poetry. In 1949, for example, Cabral wrote about "o dever ... de destruir a atroz actualidade de que o texto refere" ("Comentários" 9), which should motivate cultural and political production. Neto, writing as "António Neto," echoed this sentiment in 1951: "Há facetas da vida que é preciso melhorar. Não devemos aceitar a vida como ela é" (9). Notably, there is a heavy skepticism about poetry and poets concerned with escapism or, as Neto puts it, about " "os decadentes" who seem to feel that "a poesia é uma morfina," and who, through writing and reading poetry, seek to "fechar a porta e não ouvir o que acontece no mundo" (8). Instead, in Mensagem, poets have an obligation to respond to the outside world: "o poeta é o homem do presente e do futuro. Não pode retroceder" (Neto 10). In introducing a colloquium about Angolan poetry in 1959, the future president of Angola articulated a close relationship between the Casa's poetry and its social concerns: "É uma poesia com fins sociais, ligada intimamente aos fenómenos da vida" ("Introdução" 46). In this view, "poesia da luta" is one weapon in a broader arsenal. Nevertheless, though Mensagem is circumspect about the scope of cultural politics and more sensitive to the risk that culture could become a refuge to avoid politics, they insist that the nature of artistic selfexpression is central to building of a new order: "cantar com a nossa voz é indispensável para a harmonia do mundo" ("Introdução" 51). As at Présence Africaine, they seek to build a more universal universalism, from what they see as a richer, more polyphonic, base.

The tension between dissonance and harmony between Francophone and Lusophone struggles on the question of the relationship between culture and politics is important because it was also related to respective diagnoses of what these groups were fighting. How important they took imaginative writing to be reflected how they understood the colonialism they were all trying to dismantle. For all of them, colonialism was neither a primarily discursive phenomenon nor ever solely material without discursive implications; rather, there was a high degree of difference both within and between the different struggles about what strategy - material or discursive - of resistance to emphasize. In the Lusophone view, bringing together cultural and political practice was inevitable given the reality of colonialism as both material and a discursive oppression. They are 
explicit, however, that cultural practice is partial and its role is to preface and support a more concrete notion of "action," exemplified by the calls to action to the ultramarino movement, and by the later guerrilla struggles in which many of the Casa's students would participate. One of the key strengths of African anticolonialisms in general was their ability to build a resistance community in which these, and other, disagreements could co-exist.

Indeed, this constant oscillation between similarity and difference that I have discussed with reference to the ultramarinos and their relationship with their Francophone peers might provide a way of reading the transnational dimension of this period in the history of African anti-colonialism more broadly. The transnational movement for African liberation was not homogenous but a composite of different people with particular concerns, and the work of connecting these diverse struggles was ongoing. Alioune Diop himself, for example, emphasized the distinctiveness of the Francophone movement from its African-American counterpart. Discussing the atmosphere of growing AfricanAmerican pan-Africanism concurrent with the founding of Présence Africaine, he insisted: "the majority of the founders of Présence Africaine in Paris were unaware of many of these Pan-African meetings with DuBois... Présence Africaine was not born of a wish to follow the work undertaken by these pioneers" ("Editorial" 9). His wife, and the journal's second editor Christiane Diop, complained in an interview that Présence Africaine was often confused with the earlier magazine L'Etudiant Noir founded by the architects of Négritude, Aimé Césaire, Léopold Senghor, and Leon Damas: "They always confuse us with L'Etudiant Noir. They were not our generation. We did not know them" (Mudimbe 17). At the same time, Anglophone Africans such as the South African Es'kia Mphahele dismissed "that French-speaking thing called Négritude, whose shrine and priests are based in the offices of Présence Africaine in Paris" (50). This skepticism of the Francophone movement was more broadly echoed, inter alii, by the Nigerian writers Chinua Achebe in 1975 and Wole Soyinka in 1976 (Boehmer and Moore-Gilbert 11).

Even at the 1956 Paris conference, the sense of unity that Lima and Andrade remembered as politically exciting was often accompanied by a sense of distinctiveness, particularly between the African-American and African delegates. On the first evening, for example, Richard Wright, an AfricanAmerican writer, stood up to voice his discomfort. He described his admiration 
for the speakers he had heard that day, but spoke too of his uncertainty of how he, as an American, not an African, could relate to the "African culture" these speakers were concerned to develop. He said: "I was stupefied with admiration with what Léopold Senghor said here today.... Yet, as I admired it, a sense of uneasiness developed in me... This is not hostility, this is not criticism. I am asking a question of brothers. I wonder where do I, an American Negro, conditioned by the harsh, industrial, abstract force of the Western world ... where do $I$ stand? ... There is a schism in our relationship, not political but profoundly human" (Débats 67).

Remembering fissures at these historic moments in the development of panAfricanist consciousness is important not as a smug exercise in exposing dreams of African unity as idealist fictions. Rather, it serves to emphasize the deliberate work involved in constructing transnational solidarities that were political rather than essentialist. For collaborators at Mensagem, this was how they saw their connection with the Francophone struggle: not as a racial but as a constructed and political solidarity. ${ }^{2}$ Neto, for example, skeptical of the potential for "cultural unity" to overcome political difference, defends a materialist conception of black solidarity. "A négritude," he writes, drawing on Sartre, "não é um estado nem um conjunto definido de defeitos e de virtudes, de qualidades intelectuais e sociais, mas uma certa atitude afectiva perante o mundo" (50). For him, black unity is fundamentally grounded in "as situações sociais e culturais idênticas, todas elas caracterizadas pela opressão material e cultural do homem negro e origem comum das fontes humanas africanas" (49). At the same time, Mensagem insists that all "good" people, inside and outside Africa, could be anticolonialists, regardless of race (indeed, many of its members were white), expressing themselves open to the "colaboração de todos os homens de boa vontade" ("Editorial" (1963) 4). The "us" consists of "a unidade combativa de todos os que se irmanam nos mesmos problemas e aspirações, no mesmo amor à terra as suas gentes, na mesma autenticidade e no mesmo anseio de construção duma sociedade cada vez mais perfeita" (Soares 45).

\footnotetext{
${ }^{2}$ In 1974, at the sixth Pan-African congress, Julius Nyerere also talked about the need for the Pan-African movement to move beyond racial underpinnings, which were strategic but not essential.
} 
Where much academic communitarian and cosmopolitan political thinking freights the putative boundary between "us" and "them" with normative weight, the constantly fluctuating boundaries between part and whole that underpinned African anti-colonialisms engendered for many writers at Mensagem a certain ambivalence about the status of such boundaries. Mensagem's challenge was to find an adequate framework through which to respond to the hypocrisies of an imperial assimilation that, premised on an insistence that some people were better than others, purported to advocate unity. The ultramarinos rejected the logic of having to choose categorically between division and unity, advocating instead a vision of differentiated unity and a dialectical approach to designating the boundaries of political community. In this way, Mensagem tends to emphasize the constructedness of distinctions between "us" and "them," as well as their fluidity, even as they rely on them to resist imperialism. Who "we" are is something they themselves must build. The basis for the community is not geographically, linguistically, or racially determined, but to do with a shared politics and relationship with respect to the international status quo.

I do not mean to suggest that race was unimportant to the ultramarinos' conception of political affiliation. Clearly, race was an incredibly important issue given the crude racism of the colonial presence all African liberation struggles fought to defeat. However, one must also take into adequate account the wider anti-racist tenor of Lusophone anti-colonial thought during this moment (Gruffydd Jones). This anti-racialism was particularly palpable in the Lusophone struggle given the suffering not only of the colonized but also of many Portuguese under the Estado Novo. As Patrick Chabal notes, those Africans at the Casa who had come to study in Lisbon quickly became acquainted with the realities of fascist rule and could not ignore the poverty, ignorance, and ill health in which most Portuguese lived. Cabral, for example, "was deeply affected by this experience. Later, as the leader of the PAIGC, he often referred to the poverty of the workers and farmers of Portugal. He rarely discussed the Portuguese political situation without emphasizing, often in great detail, the implications of fascist rule for the mass of the Portuguese people" (Chabal 40).

These fragments from the histories of African anti-colonial movements bring into view a constitutive oscillation between their members' sense that they were united in a common, structural, international struggle on the one hand, and on the other, a sense that their particular struggles were specific and locally instantiated. 
At the same time, these structural/particular commitments were juxtaposed with a more expansive reach toward the whole of humanity. The great strength of this conception of a dispersed political community built by a gathering of the willing was that, when there was a clear conception of what they were fighting against (colonialisms), this inclusive vision allowed many different people to unite and mobilize under a broad banner. The limitations for such a community bound together by a shared politics were that when the goal changed, the community dispersed, as evinced not only by the fractures between the Lusophone and Francophone groups in the mid-sixties (when the former were still colonies and the latter already independent), but also by the civil wars that followed independence in Angola and Mozambique.

Looking at the writings of Lusophone anti-colonialists should remind us that it is important not to overstate the specificity of Portuguese colonialism. Rather, working with the conceptual architecture and theoretical lexicons developed by those who struggled against it, we can read Portuguese imperialism itself through a lens of differentiated unity, seeking to understand not only how it differed from but also how it shared logics, concepts, and strategies with other European colonial projects. In this way, working back and forth between particularity and similarity, we might enrich our understanding of how colonialisms, past and present, European and otherwise, resemble one another amid all their historical, linguistic, and geographic specificities. With a focus on how corollary resistance movements have diagnosed and written about the specific problems they faced while working with and learning from one another, this dialectical approach might prove to be both politically exciting and theoretically productive, just as it did for the students at the Casa.

\section{Works Cited}

Associação Casa dos Estudantes do Império. Cinquentenário da Fundação da Casa dos Estudantes do Império 1944-1994. Lisbon: Associação Casa dos Estudantes do Império, 1997. Print.

Aydin, Cemil. "Pan-Nationalism of Pan-Islamic, Pan-Asian, and Pan-African Thought." The Oxford Handbook of the History of Nationalism. Ed. John Breuilly. Oxford: Oxford UP, 2013. 672-93. Print. 
Boehmer, Elleke, and Bart Moore-Gilbert. "Introduction to Special Issue [on] Postcolonial Studies and Transnational Resistance.” Interventions 4.1 (2002): 7-21. Print.

Cabral, Amílcar. "Comentários.” Mensagem 1.7 (1949): 7-9. Print.

—. "Poema." Mensagem 2.11 (1949): 16. Print.

—. Unidade e Luta. Lisbon: Seara Nova, 1976. Print.

Castelo, Cláudia. "Casa dos Éstudantes do Império (1944-1965): Uma Síntese Histórica." Mensagem: Cinquentenário da Fundação da Casa dos Estudantes do Império, 1944-1994. Lisbon: Associação Casa dos Estudantes do Império, 1997. 23-30. Print.

Chabal, Patrick. Amílcar Cabral: Revolutionary Leadership and People's War. Cambridge: Cambridge UP, 1983. Print.

Craveirinha, José. "Poema do Futuro Cidadão." Nouvelle Somme de Poésie du Monde Noir. Présence Africaine 57.1 (1966): 475-76. Print.

—. "Sonho." Mensagem 16.1 (1964): 25. Print.

“Decreto n.18:570." Diário do Govêrno 8 July 1930. Print.

"Débats." Présence Africaine 8-10 (1956): 66-226. Print.

Des Etudiants d'Afrique Portuguaise. "Situation des Étudiants Noirs dans le Monde." Présence Africaine 14 (1952): 223-40. Print.

Diop, Alioune. “Discours d'Ouverture.” Présence Africaine 8-9-10 (1956): 9-19. Print.

—. "Editorial." Présence Africaine 92.4 (1974): 9-14. Print.

"Editorial." Mensagem 2.3 (1959): 4-5. Print.

"Editorial." Mensagem 15.1 (1963): 3-4. Print.

Fanon, Frantz. "The Reciprocal Basis of National Cultures and the Struggles for Liberation." Présence Africaine 24.5 (1959): 89-97. Print.

Faria, António. A Casa dos Estudantes do Império: Itinerário Histórico. Lisbon: Câmara Municipal-Biblioteca Museu República e Resistência, 1995. Print.

Ganhão, Fernando. "Escritores Falam." Mensagem: Cinquentenário da Fundação da Casa dos Estudantes do Império, 1944-1994. Lisbon: Associação Casa dos Estudantes do Império, 1997. 149-55. Print.

Glick Schiller, N. "Old Baggage and Missing Luggage: A Commentary on Beck and Sznaider's 'Unpacking Cosmopolitanism for the Social Sciences: A Research Agenda.’” British Journal of Sociology 61(2010): 413-20. Print. 
Gomes, Benedito. "Pequena História da Casa dos Estudantes do Império." Mensagem 1.4 (1958): 7-8. Print.

Gruffydd Jones, Branwen. "From Rupture to Revolution: Race, Culture, and the Practice of Anti-Colonial Thought." African Identities 13.1 (2015): 4-17. Print.

Jules-Rosette, Bennetta. "Conjugating Cultural Realities: Présence Africaine." The Surreptitious Speech: Présence Africaine and the Politics of Otherness, 1947-1987. Ed. V.Y. Mudimbe. Chicago: U of Chicago P, 1992. 14-44. Print.

Lara, Alda. "Presença." Mensagem 14.2 (1962): 10-11. Print.

Laranjeira, Pires. "Introdução: Uma Casa de Mensagens Anti-Imperiais." Mensagem: Boletim Casa dos Estudantes do Império. Ed. Orlanda Amarílis and Pires Laranjeira. Vol 1. Lisbon: ALAC, 1996. xi-xxxi. Print.

Lima, Manuel dos Santos. "Escritores Falam." Mensagem: Cinquentenário da Fundação da Casa dos Estudantes do Império, 1944-1994. Lisbon: Associação Casa dos Estudantes do Império, 1997. 149-55. Print.

Machado, José Pedro. Dicionário Etimólogico da Língua Portuguesa. Vol. 3. Lisbon: Confluência, 1967. Print.

Martins, Ovídio. "Mudança.” Mensagem 15.2 (1963): 45. Print.

Mateus, Dalila Cabrita. A Luta pela Independência: A Formação das Elites Fundadoras da FRELIMO, MPLA e PAIGC. Lisbon: Inquérito, 1999. Print.

Monteiro, César. "Palavras de Abertura." Mensagem 3.1 (1960): 4-5. Print.

Mourão, Fernando. “Antologia de Poesia Negra de Expressão Portuguesa por Mário de Andrade.” Mensagem 3.1 (1960): 9-10. Print.

Mphahlele, Ezekiel. “The Cult of Négritude.” Encounter (March 1961): 50-52. Print.

Neto, Agostinho. "Introdução a um Colóquio sobre Poesia Angolana." Mensagem 3.5-6 (1960): 45-51. Print.

Neto, António. “A Decadência na Poesia.” Mensagem 3.12 (1951): 6-10. Print. Pereira, Alberto Rui. "Pelo que Lutamos.” Mensagem 15.2 (1963): 6-44. Print.

"Poesia Africana de Expressão Portuguesa: Breve Nota Explicativa." Présence Africaine 57.1 (1966): 433-34. Print.

Power, Marcus. "Exploding the Myth of Portugal's 'Maritime Destiny': A Postcolonial Voyage Through EXPO '98." Postcolonial Geographies. Ed. Alison Blunt and Cheryl McEwan. New York: Continuum, 2002. 132-46. Print. 
Prashad, Vijay. The Darker Nations: A People's History of the Third World. New York: New Press, 2007. Print.

Rao, Rahul. Third World Protest: Between Home and the World. Oxford: Oxford UP, 2010. Print.

Rodrigues, Sarmento. "Doc. 1." Mensagem: Cinquentenário da Fundação da Casa dos Estudantes do Império, 1944-1994. Lisbon: Associação Casa dos Estudantes do Império, 1997. 171-75. Print.

Rosas, Fernando. "A CEI no Contexto da Política Colonial Portuguesa." Mensagem: Cinquentenário da Fundação da Casa dos Estudantes do Império, 1944-1994. Lisbon: Associação Casa dos Estudantes do Império, 1997. 13-22. Print.

Soares, Francisco. "Mensagem, Neo-realismo e Negritude." Mensagem: Cinquentenário da Fundação da Casa dos Estudantes do Império, 19441994. Lisbon: Associação Casa dos Estudantes do Império, 1997. 45-50. Print.

Sousa, Noémia de. "Se me quiseres conhecer." Mensagem 14.3 (1962): 47. Print. Sousa, Vítor de, and Moisés de Lemos Martins. "A 'portugalidade' no Discurso Parlamentar Português: Assembleia Nacional (1935-1974) e Assembleia da República (1976-2012)." Comunicação e Cultura: II Jornada de Doutorandos em Ciências da Comunicação e Estudos Culturais. Ed. Zara Pinto-Coelho and Joaquim Fidalgo. Braga: Centro de Estudos de Comunicação e Sociedade, U do Minho, 2013. 87-103. Print.

Tagore, Rabindranath. The Home and the World. London: Macmillan,1919. Print.

Tenreiro, Francisco José. “Processo Poesia.” Mensagem 15.1 (1963): 5-11. Print. 